\title{
anemon
}

Muş Alparslan Üniversitesi Sosyal Bilimler Dergisi

Journal of Social Sciences of Muş Alparslan University

Yı//Year: 2016 • Cilt/Volume: 4 • Sayı/Number: 2

ISSN: 2147-7655 • e-ISSN: 2149-4622

ÖZGÜN ARAŞTIRMA • ORIGINAL ARTICLE

\section{Kültürlerarası İletişim Bağlamında Alevi- Sünni Dikotomisi: Tunceli ve Elazığ Örneği}

\author{
Mustafa YAĞBASAN ${ }^{1, a}$, Ali ÖZTÜRK ${ }^{2}$ \\ ${ }^{1}$ Prof. Dr., Fırat Üniversitesi, İletișim Fakültesi, Gazetecilik Bölümü - Elazığ/ Türkiye \\ ${ }^{2}$ Fırat Üniversitesi, İletişim Fakültesi, Halkla İlişkiler ve Tanıtım Bölümü - Elazığ/ Türkiye
}

Başvuru tarihi: 17 Mart 2016 Düzeltme tarihi: 17 Mayıs 2016 Kabul tarihi: 20 Mayıs 2016

Öz

Anadolu coğrafyası çok kültürlü yapısıyla zengin bir görünüm arz etmektedir. Türkiye'de etnik anlamda Türk ve Kürt kültürleri, teolojik anlamda ise Alevi ve Sünni inanışları baskın ve başat konumları ile dikkat çekmektedir. Alevi ve Sünni toplumları şüphesiz geçmişten günümüze dek farklı alanlarda birbirleriyle iletişim ve etkileşim içerisinde olmuşlardır. Siyasi mülahazalar bir tarafa bırakıldığında adı geçen kültürlerarasındaki uyuşmazlık ve iletişimsizliklerin daha ziyade önyargılara dayalı olarak marjinal boyutta kaldığını söylemek mümkün görünmektedir.

$\mathrm{Bu}$ çalışmanın temel amacı, Türkiye'de farklı inanç kültürüne sahip olan Alevi ve Sünni toplumların birbirleriyle olan iletişimlerinin hangi boyutta olduğunu ortaya koymaktır. Araştırmanın bahsi geçen inanç kültürlerinin birbirlerini nasıl algıladıklarını, kurdukları bağların ve komşuluk ilişkilerinin hangi düzeyde olduğunu, gelenekler arasındaki farklılıklara veya benzerliklere nasıl baktıklarını incelemesi açısından önem arz etmektedir. Nesnel verilere ulaşmak amaciyla bu araştırmada Türkiye evreninden hareketle Tunceli ve Elazığ illeri örneklem olarak seçilmiştir. Veriler SPSS programında analiz edilmiş ve yorumlanmaya çalışılmıştır. Araştırma sonucunda Alevi ve Sünni inançları arasındaki iletişime, etkileşime ve algıya yönelik önemli bulgulara ulaşılmıştır.

\section{Anahtar Kelimeler}

Kültürlerarası İletişim, Mezhepler, Alevi-Sünni

\footnotetext{
a Sorumlu Yazar/Correspoding Author: Fırat Üniversitesi, İletişim Fakültesi, Gazetecilik Bölümü, 23119, Elazığ/ Türkiye. e-posta: myagbasan@firat.edu.tr 


\title{
Alawi-Sunni Dichotomy with Respect to The Intercultural Communication: The Case of Tunceli and Elazı̆
}

\begin{abstract}
The geography of the Anatolia presents a rich appearance with its multicultural structure. Turkish and Kurdish cultures are ethnically and Alawi and Sunni beliefs are theologically dominant and draw attention with their dominant status in Turkey. There is no doubt that Alawi and Sunni societies have communicated and interacted with each other in various areas from the past to the present. When political contemplations are put aside, it is possible to say that the discrepancy and the lack of communication between the mentioned cultures stay at the marginal dimension mostly based on prejudices.
\end{abstract}

The main purpose of this study is to put forward what the extent of communication of the Turkish and Alevi societies having different belief cultures in Turkey is. The study is of great importance in terms of studying how the mentioned cultures realize each other, at what level the links and the neighbor relations are, and what they think about the differences and the similarities between the traditions. Tunceli and Elazı ğ cities in Turkey have been selected as samples in order to obtain objective data. The obtained data have been analyzed with SPSS program and have been tried to comment on. In conclusion, significant findings about the communication, interaction and realisation between the Alawi and Sunni beliefs have been obtained.

\section{Keywords}

Intercultural Communication, Sects, Alawi-Sunni

\section{GİRIŞ}

Yerkürenin tüm coğrafyalarında olduğu gibi Anadolu coğrafyasında da farklı kültür ve etnik yapılar mevcuttur. Bu farklıkların en belirgin olanlarından bir tanesi de kuşkusuz Alevi ve Sünni inanışlarıdır. Tarihsel süreçte farklı nedenlere dayalı olarak çatışma ve çekişme içerisinde oldukları bilinen bu mezhepsel oluşumların çoğu zaman pozitif etkileşim içerisinde olduklarını bilinmektedir. Ancak marjinal düzeyde kalan negatif algıların ise önyargılara dayalı olduğu ve bu durumdan daha ziyade Alevi toplumunun olumsuz etkilendiği görülmektedir. Bu bağlamda bilinen en yaygın önyargıya 'mum söndü’ hadisesi örnek olarak gösterilebilir. Diğer taraftan Alevi toplumunda ise Sünni mezhebe dair oluşan 'gerici', 'yobaz' gibi kanaatlerin sıkça dillendirildiği bilinmektedir. Sonuç olarak bu tür olumsuzlukların iki inanç arasındaki iletişimin negatife dönüşmesine etki ettiği söylenebilir. Nesnel dayanaklardan yoksun bu tür enformasyonların geçekleri yansıtmadığına dair bir kanaatin oluşturulması ilişkilerin olumlu yönde seyrine kuşkusuz katkılar sağlayacaktır. 
Günümüzde etnik ve mezhepsel oluşumlar artık belli coğrafyalara hapsolmuş değildir. Sanayileşme ve kentleşmeyle birlikte kırsaldan şehirlere veya metropollere yaşanan göçlerin etkisiyle Alevi ve Sünni toplumları arasındaki komşuluk ve arkadaşlık ilişkilerinde doğal olarak bir geçişkenlik yaşanmaya başlanmış ve pozitif iletişim ve etkileşim süreci ivme kazanmıştır. Dolaysıyla farklı inanış ve kültürlere dair olumsuz algılarının da zaman içerisinde değiştiği söylenebilir. Hiç şüphesiz süreç mevcut önyargıların minimize olmasına da katkı sağlamıştır. Ancak sürecin olumlu bu yönüne karşın metropollerde çoğu zaman mezhepsel ve kültürel bir gettolaşmanın oluştuğu bilinmektedir. Bu durum kuşkusuz 'kapalı toplum' düzenin muhafazasına ve potansiyel olarak mezheplerarası iletişim sürecini olumsuzlaşmasına neden olabilmektedir. Ancak süreci olumsuzlaştıran sebeplerin mezhepsel olmaktan çok daha ziyade siyasal mülahazalara dayalı olduğu gözlemlenebilmektedir. Bu çalışmanın amacı; Alevi ve Sünni toplumları arasındaki etkileşimlerin ve iletişimsel ortamların hangi düzeyde olduğunu belirlemeye yöneliktir. Bu düzlemde yürütülen çalışmada önemli bulgulara ulaşılmıştır.

\section{KURAMSAL, KAVRAMSAL ÇERÇEVE VE LITTERATÜR}

\subsection{Kuramsal Çerçeve}

Kültürü oluşturan birçok parametreden söz etmek mümkündür ve kültür aynı zamanda bireylerarası etkileşimin ve iletişimin de temel nüvesini oluşturmaktadır. Şüphesiz inanış ve ibadet anlayışı da bu temel tasnif arasında yer almaktadır. Gay, kültürü tanımlarken; "sosyal sınıf, din, dil ve etnik köken gibi farklılıklar kişilerarası etkileşimde toplumun temel özellikleridir" ifadesini kullanmaktadır (Gay aktaran Çırık, 2008: 31-32). Aslında bu tür farklılıkların sosyal ilişkilerde ve bireylerarası iletişimde birer "zenginlik" olarak addedilmesi gerekir. Ancak çoğu zaman bu tür farklılıkların ayrıştırıcı unsurlar olarak öne çıktı̆g 1 da görülebilmektedir. Zira farklılıklar; "toplumların kutuplaşmasına, insanların birbirleriyle etkileşimlerinin kesilmesine ve toplumdan uzaklaşmalarına neden olmaktadır" (Çırık, 2008: 31-32). Yerkürenin tüm coğrafyalarında olduğu gibi Anadolu coğrafyası da tek bir kültürden, mezhepten veya etnik yapıdan oluşmamaktadır. Türkiye'nin farklı etnik ve mezhepsel yapısı multikültürel bir toplum olduğunun göstergesidir ve aslında değerlendirilmesi gereken bir sermayedir. Diğer taraftan demografik zenginlik kültürel algıyı ve öğrenmeyi de kolaylaştırabilmektedir. Ancak pozitif bu ortamlardan istifade etmek yerine çoğu zaman siyasi çatışmalar ve ayrıştırmalar için kullanıldığını söylemek mümkün görünmektedir.

Farklılıkları içselleştirmiş grupların öğrenme ve toplumsallaşma süreci elbette daha hızlıdır. Öğrenme ve öğretme, sosyal bağlam içerisinde, kültürel etkileşimler sonucunda gerçekleşmektedir. Kültürün deneyimlenerek öğrenilen bir süreç olduğu da göz önünde bulundurulduğunda; “. .. farklı kültürlerin analiz edilip değerlendirilmesinin, bireyin gelişimine önemli oranda katkı sağlayacağı söylenebilir" (Çırık, 2008: 31-32). Bu bağlamda yapılacak olan bilimsel çalışmalar ve değerlendirmeler bazı önyargıların nesnel verilere dayalı olarak ortaya konulmasına ve olumsuz algıların ortan kaldırılmasına katkı sağlayacaktır.

Kültür çatışması kuramı kavramsal olarak ilk defa Amerika'da, artan suç oranlarından göçmenleri sorumlu tutmak amacıyla ortaya atılmıştır. Çatışma, iki kültürün birbirini 
dışlamaya çalışması sonucunda doğmaktadır. Kültür çatışması kuramına göre, bu kültür çatışmasının içinde yaşayan göçmenler, yabancı işçiler, etnik azınlıklar suç işlemeye daha yatkındır (Karasu, 2008: 261). Bu konuda ilk kuramsal çalışmalar Chicago Okulu'nca yapılmıştır. Kent ve suç ilişkisine yönelik sosyolojik kuramları; Chicago Okulu'nun geliştirdiği 'ekolojik yaklaşım', 'anomi kuramı' ve 'kültür çatışması' kuramları şeklinde sıralamak mümkündür (Karasu, 2008: 259). Ancak bu çalışmaya dayanak oluşturan temel kuramsal yaklaşım 'kültürel dışlanma'dır. Kültürel dışlanma; ekonomik nedenlerden bağımsız olarak, toplumsal ve kültürel hayata dilediğince katılamama durumudur. Örneğin; bulunulan coğrafyadaki çoğunluk referans alındığında farklı bir etnik kökenden/ırktan gelmek ya da farklı bir din/mezhep üyesi olmak, çoğunluk dilini rahat konuşamamak ya da aksanlı konuşmak, farklı giyim kuşam ya da cinsel tercihler gibi nedenlerden ötürü toplumsal yaşamın genelinde süregitmekte olan etkinliklere alınmamak, soğuk davranılma ve engellerin çıkartılması şekillerinde tezahür etmektedir.

Yukarıdaki yargılarla bağlantılı olarak, kültür çatışmasının sadece farklı kültürlere sahip topluluklar arasında olduğunu söylemek yanlış olur. Çarkoğlu ve Toprak'a göre (2006: 95-96), “Türkiye'de de ‘biz” ve “ötekiler' türü bir ayrışmanın mevcudiyetinden söz etmek mümkündür. $\mathrm{Bu}$ ayrışma toplumun içe dönüklüğünün de bir göstergesidir. Kişiler çok kültürlü bir toplum yapısı dâhilinde ortak değerler geliştirmeye hevesli gözükmemektedirler. Burada 'biz' Türk-Müslüman-Sünni, 'öteki' ise Kürt, Alevi ve gayr-1 Müslim olarak nitelendirilebilir’. Örneğin Adaman ve Keyder'in (2006) yapmış oldukları çalışmada belli gruplara yönelik kültürel, sosyal ve politik dışlamanın olduğu tespit edilmiştir. Bahsi geçen bu çalışmada katılımcıların beşte biri etnik köken sebebiyle dışlandıklarını dile getirmiştir. Bu tespitler sosyal dışlanmanın kaçınılmaz olarak mekânsal ayrımcılıkla bir arada bulunduğunu da göstermektedir. Dolaysıyla sosyal dışlanmanın kökenini günümüz Türkiye'sinde yalnızca yoksullukta aramamak gerekir. Ötekileştirmenin ve çatışmaların sosyolojik bu boyutuna ilaveten etnik ayrımcılığın ve damgalamanın da önemli bir etken olduğu bu bağlamda göz ardı edilmemelidir.

Türkiye'de terörden dolayı kırsaldan şehirlere ve özellikle de Batı illerine yoğun bir göçün yaşandığı bilinmektedir. Bu bağlamda oluşan gettoların bazen ürkütücü boyutlara ulaştığ1 görülebilmektedir. Bu durum kuşkusuz Alevi toplumu için de geçerlidir. "Insanlar kentsel mekânda tıpkı tabiattaki bitki ve hayvan gruplarının belli alanlarda toplanması gibi belli mahalle ve semtlerde toplanmakta, sosyal ve kültürel birlikler oluşturmaktadırlar. Ancak belirli bölgelerde yoğunlaşan ve yerlerinden edilmiş kişiler işverenler tarafindan ucuz işgücü, ev sahipleri tarafindan da evsiz, çaresiz kişiler olarak sömürülmektedirler. Dolayısıyla, zorunlu göç mağdurlarının kentlerin kenar bölgelerinde yoğunlaşmaları dışlanmalarını artıran bir etken olarak görülebilir" (Adaman ve Keyder, 2006: 51). Yapısal değişiklikler fiziksel yapıyı etkilediği gibi, kişilerin davranışlarını, heyecanlarını, yaşam biçimini de etkiler (Karasu, 2008: 260-274). Bu düzlemden hareketle; çalışma mezhepsel anlamda 'dışlanmanın' ve ‘ötekileştirilme'nin nesnel verilere dayalı olmadığı temel hipotezi üzerine kuruludur ve bu bağlamdaki varsayımları test etmeye yöneliktir. 


\subsection{Kavramsal Çerçeve ve Literatür}

\subsubsection{Sosyolojik Açıdan Kimlik ve Mezhep}

Kimlik, bireyin taşıdığı sıfat/sıfatların bütünüdür. Sosyal yaşam içerisinde birçok kimliğe sahip olan birey, duruma, şartlara veya ihtiyaçlara göre bunlardan birini veya birkaçını aynı anda baskın olarak kullanma ihtiyacı hissedebilmektedir. Birey kimliklerinin birçoğunu hayatı boyunca edindiği deneyimlerle belirlemektedir. Ancak mensubu bulunduğu örneğin 'etnik köken' veya 'mezhep' gibi unsurlara insanın çoğu zaman müdahil olabilme şansının bulunmadığı ve sorgulama ihtiyacı hissedilmeden kabul edildiği bilinmektedir. Diğer taraftan kimlik/kimlikler etkileşimler yolu ile de kazanılabilmektedir. Kimlik, tarihten günümüze değin bireyin tanınması veya isimlendirilmesi ile de ilintili bir husus olmuş ve kimliğe 'şeref' atfedilmiştir. Kimlik kuşkusuz aynı zamanda sosyolojik anlamda ihtiyaç ve zorunluluktur. Bireyi tanımlayan temel nitelikler arasında yer alan ve tanınma/tanınmama, bazen de yanlış tanınma yoluyla biçimlendirilen kimlik, içinde bulunulan toplum tarafindan nesnel olmayan bir imaj yansıtması durumunda ise bireyin zarar görmesine ve çarpıtılmış bilgilerle baskı altında kalmasına neden olabilmektedir.

Sünni ve Alevi inanışları İslam'ı birbirlerinden farklı biçimde algılamaları ve yaşamaları ile anlam bulmaktadır ve kendilerine has duruşları olma iddiaları vardır. Teolojik tüm oluşumlarda olduğu gibi 'irşat' anlayışıyla çeşit kültürel yapılara ve ulaşabildikleri tüm coğrafyalara mesajlarını iletme gayreti içerisindedirler. Ancak farklı sosyokültürel coğrafyalarda 'ilahi' mesajların farklı algılanması her zaman mümkündür. Yani mesaj, her yörede oranın kültürel özellikleriyle harmanlanarak algılandığı için yeni bir yapı ve anlam içerecek şekilde yeniden inşa olur; ancak din içerisinde birbirlerinden farklılaşan grupların ortaya çıkması aynı zamanda birbirleriyle çatışmasını da beraberinde getirmektedir; çünkü ister din, ister mezhep, isterse cemaat seviyesinde olsun, her inanç grubu hakikati bizzat kendisinin temsil ettiğini iddia ederek ötekileri şu ya da bu şekilde dışlamaya başlar (Watt ve Albayrak'dan aktaran Yapıcı, 2009: 54). Bu süreçte etnosantrik eğilimler kendisini daha çok hissettirdiği için 'öteki' olarak algılanan alt dinî gruplar 'dinden çıkmakla', 'sapkın', 'sapık' ve 'kötü' olmakla suçlanırlar. Süreç aslında zihinsel anlamda sosyal gruplama (kategorizasyon) ile duygusal anlamda sosyal kiyaslamanın doğal bir ürünüdür. Önce ‘biz' ve 'onlar' kategorik ayrımı ortaya çıkar. Bu ayrım tarihsel, dinsel ve sosyokültürel gerekçelerle temellendirilir. Grup içi benzerlikler, gruplar arası farklılıklar ısrarla vurgulanır; ancak bu yeterli değildir; çünkü eğer grup, üyelerine saygın bir kimlik algısı sunmuyorsa varlığını devam ettiremez. Bu sebeple diğer grup ya da gruplarla kıyaslamalar yapılır (Turner'den akataran Yapıc1, 2009: 54) ve sosyal mesafe normları devreye sokulur, bu normlar grubun değer yargısı ve dünya görüşü hâline getirilir.

Kendi aralarında kısmi farklılıklar olmakla birlikte Sünniler genellikle Kur-an, sünnet ve fikıh üzerinden şekillenen bir din ve kimlik algısına sahiptir. Sünnilere göre ideal bir Müslüman dinî, ahlaki ve geleneksel değerleri yaşayan ve yaşatmaya çalışan "gerçek bir Müslüman” olmalıdır. Onlara göre Müslümanlığın aslı budur. Bunun dışındaki yorumlar heterodokstur, yani İslam dışı unsurların katılmasıyla bulanıklaşmıştır. Dolayısıyla saf değildir. Sünni çerçeveden bakıldığında belli bir kesimin Alevileri az da olsa 'sapık 
inançlı' olarak addettikleri söylenebilir. Bu yaklaşım temelde 'mülhid', 'rafizi', 'zındık' ve 'dinsiz' gibi kalıp yargılarıyla yakından ilişkilidir. Buna yakın dönemlerde 'kızılbaş', 'komünist' vb. yakıştırmalar da eklenmiştir. 'Abdestsiz' ya da 'gusülsüz' gibi söylemler de yine bu kapsamda değerlendirilebilir. Aslında en fazla yaralayıcı ve aşağılayıcı itham cinsel ilişkide serbestlik çağrışımı yapan 'mum söndü' önyargısıdır (Türkdoğan'dan aktaran Yapıc1, 2009: 55).

$\mathrm{Bu}$ ön yargı diğer ithamlarla birleşince Aleviler, Yahudi ve Hıristiyanlardan daha uzak bir sosyal mesafeye yerleştirilmiştir. Öyle ki Dumont'un da belirttiği gibi bazı yörelerde: "Bir Alevinin Müslüman olabilmesi için önce Yahudi, sonra Hıristiyan daha sonra da Müslüman olması gerekir" şeklinde dile getirilen söylemler ortaya çıkmıştır. Sezgin de bazı bölgelerde: "Alevilerin Müslüman olabilmesi için ayaklarının altına bir kiremit ya da tuğla almaları ve o eriyene kadar yıkanmaları gerekir" şeklinde ifade edilen kalıp yargıların var olduğundan söz etmektedir (Yapıcı, 2009: 55).

Kendi aralarında çok ciddi farklılıklar görülse de Alevilerin İslam algısı Sünnilerin İslam algısından oldukça farklıdır. Bu farklılık tarihsel süreçte yaşananlarla birleştirilip yeniden üretilince Sünniler özellikle 'Yezit' kavramı üzerinden algılanıp damgalanmıştır. Onlara göre Kerbela faciasının sorumlusu olmaları hasebiyle Sünniler 'Yezidin ahfatları', 'Yezidin çocukları', 'Mervan' ve 'Münkirdir'. Buna bağlı olarak; "Varma Yezidin yanına, siner kokusu tenine" deyişinin Aleviler arasında yaygın bir şekilde kullanıldığı da bilinmektedir. Günümüzde ise yöresel farkl1l1klarla birlikte, 'yoz', 'yobaz', 'gerici', 'şeriatçı', 'muhafazakâr', 'modernleşemeyen', 'yabancı', 'sakallı' vs. tarzında kalıp yargıların dillendirildiği kaydedilmektedir (Engin ve Türkdoğan'dan aktaran Yapıcı, 2009: 55).

Tarihsel süreçten bugüne Sünni ve Alevi gruplarının birbirlerini çok çeşitli ithamlarla yaralamalarının arkasında kendi kimliklerini koruma arzuları yatmaktadır. Her ne kadar kendi aralarında az miktarda farklı görüşler taşıyanlar olsa da Alevilerin geneli Müslüman üst kimliği altında Alevi'ce yaşayıp Alevi olarak ölmeyi, yani kimliklerinden taviz vermeden varlıklarını devam ettirmeyi istemektedir. Günümüzde halen Aleviler tarafından sıkça gündeme getirilen; "Alevi köylerine zorla cami yaptırıldığı", "Din Kültürü Ahlak Bilgisi derslerinde sadece Sünni Müslümanlığın anlatıldığı", "Diyanet İşleri Başkanlığının İslamiyet'in sadece Sünni yorumuna göre yapılandığı ve hareket ettiği", "Devlet eliyle Alevilerin Sünnileştirilme çabası içerisine girildiğì" ve nihayetinde "dışlandıkları, ayrımcılığa maruz bırakıldıkları, hatta yok sayıldıkları" yönündeki şikâyetler de Alevilerin sosyal, kültürel ve dini kimliklerini koruma arzularının yansıması olarak kabul edilebilir.

Dışlanan kadar dışlayanlar da kimliklerini ötekinin tehdidi altında hissettiği için her iki grup arasındaki ilişkiler etnosantrik bir görüntü içerisinde şekillenmeye devam etmektedir. Ancak insanların bilgi seviyesinin giderek artması, kültürel çoğulculuğun artık bir vakıa olarak kabul edilmeye başlanması, toplumda liberal eğilimlerin kuvvetlenmesi, demokratik yaşam biçimini benimseme sürecinde belli bir mesafe kat edilmesi vb. olgular Alevilerle Sünniler arasındaki ön yargıların kısmen zayıflamasına yol açmış görünmektedir. Özetle, Sünni ve Alevi grupların birbirleriyle ilişkilerini belirleyen temel faktör sosyal kimliklerdir; çünkü ötekinden farklı olma olgusu, ne açıdan farklı olduğuna bakılmaksızın gruplar arası ilişkileri belirlemeye hizmet etmektedir. $\mathrm{Bu}$ 
sebeple Sünniler ve Aleviler kendilerini değerlendirirken daha ziyade olumlu, karşı tarafı değerlendirirken ise genelde olumsuz sıfatları atfetme eğilimi içerisindedirler. Her iki alt dinî-sosyal grubun birbirlerini algılamalarında tarihsel süreçte yaşanan acı tecrübeler ve tortuların etkisi hâlâ hissedilmektedir. Bunları yok etmek kolay değildir; zira Einstein'e atfedildiği üzere: "Ön yargıları parçalamak atomu parçalamaktan daha zordur." Bir yerde farklı bir grup kimliği varsa o kimlik mutlaka ötekine rağmen, ama ötekiyle birlikte mevcuttur; çünkü hiçbir grup, dolayısıyla hiçbir kimlik tek başına var olamaz. Burada asıl önemli olan farklılıkların farkında olarak birlikte yaşayabilmenin imkânlarını bulabilmektir" (Yapıc1, 2009: 57-58).

\subsubsection{Alevilik}

Bilindiği gibi, sözlükte 'Ali'ye mensup', 'Ali'ye ait' ve 'Ali soyundan olan' anlamlarına gelen Alevî kelimesine terim olarak siyasi, itikadi ve tasavvufî açıdan çeşitli anlamlar yüklenmiştir. Bu terim siyasi alanda, Hz. Ali'nin birinci halife olması ve halifeliğin onun soyundan gelenlerce yürütülmesi gerektiği yönündeki kabullere sahip olanlar için kullanılmıştır. İtikadi alanda ise Hz. Ali'yi üstün olarak görenlerin yanı sıra, peygamberlik konusunda paye verenlerden uluhiyyet atfedenlere kadar pek çok fraklı inanç taşıyanlar bulunmaktadır. Tasavvuf alanında silsilelerini Hz. Ali'ye dayandıran tarikatlar genel olarak Alevîliği 'meşrep' olarak isimlendirilmiş, aynı zamanda cehrî zikri tercih eden tarikatlar da Alevî kelimesi ile nitelendirilmiş ve bu görüşü benimseyenlerin piri olarak kabul edilmiştir (Üçer, 2005: 163-166).

Alevîliğin, inanç esasları noktasında farklı kabul ve yorumları bulunmakla beraber büyük oranda temel İslami inançları benimsediği görülmektedir. Bu durumu Hak-MuhammedAli üçlemesi bağlamında ulûhiyet-nübüvvet-velayet çerçevesinde yorumladıkları bilinmektedir. Ehl-i Beyt merkezli bir dünya ve ahiret görüşünü benimseyen Alevilik inancı ibadet hayatını tarikat hayatı kalıplarında şekillendirip sadece bu alana hasretmiştir. Alevilik, diğer gruplarla olan ilişkilerinde tevella ve teberrayı temel prensip olarak görmektedir. İlham ve keşfi bilgi kaynăğ, eline-diline-beline sahip olmayı ahlâkî ilke ve soya (ocaklara) dayalı tarikatlar için bir üst kimlik, kavram ya da bir ortak şemsiye olarak kabul etmekte ve benimsemektedir (Üçer, 2005: 163-166).

Ali ile Peygamber arasında en küçük görüş ayrılığı bulunmaz. Ali, Muhammed'e derin saygı, Peygamber'in ise Ali'ye büyük sevgisi vardır. Peygamber; "Ben bilimin kenti isem, Ali onun kapısıdır" diyerek onu değerlendirir. Böylece aralarında sıkı bir düşünce birliği, eylem uyumu vardır. Nitekim Alevîler de Ali ile Muhammed arasında bir görüş ayrılığı olduğunu kabul etmezler. Ancak, İslam'ın gerçek biçiminin Alevîlik olduğunu Muhammet'ten sonra gelen ilk üç halife döneminde İslam'ın gerçek yapısının bozulduğunu ileri sürer ve Emeviler döneminde İslâmın tümüyle yıkıldığını savunurlar (Bozkurt, 2010: 7-8).

Bugünkü anlamda Anadolu'da birinci dönem itibariyle (ki bu da miladi on altıncı asrın başlarına tekabül eder) Alevilikten bahsetmek mümkün görülmemektedir. Genellikle Osmanlı Devlet vesikalarında Kızılbaş ve Rafizi olarak adlandırılan ve bu isimlerle anılan bu toplum on dokuzuncu yüzyıldan itibaren Alevi ismini kullanmaya başlamıştır (Dalkıran, 2002: 103-108). 


\subsubsection{Sünnilik}

Kelime anlamı itibariyle 'gidilen yol' ve 'mecra' anlamları taşır. IV. yüzyıldan günümüze kadar, Sünnî Müslüman dünyasının büyük çoğunluğunda 'dört mezhep' (mezahib-i erbaa) diye meşhur olan ve sırasıyla; Hanefî, Maliki, Şafii, Hanbelî mezheplerinin hâkim olduğu fetva, kaza ve eğitim müesseselerinin, bu mezheplerin etkisinde olduğu görülmektedir. Erken dönem fikıh çevrelerinde ve ardından teşekkül eden mezheplerin ders halkalarında yetişen öğrenciler, yaşadıkları bölgelerin bir yandan fetva ve kaza makamlarında bulunmuşlar, öte yandan yüksek hukuk kültürünü şekillendirmişlerdir. Fıkıh, fert ve toplum hayatının hemen her alanını kapsadığından, fikıh mezheplerinin İslâm toplumu üzerindeki etkileri siyasî, itikadi ve tasavvufî zümreleşmelere nispetle daha güçlü olmuştur (Ünverdi, 2011:3-8).

Selçuklu döneminden önce var olan Hanefi-Şafii gerilimi, Selçuklu yönetiminin, Eş’ariŞafii bloklaşması karşısında Maturidi-Hanefi görüşüne destek vermesi, Maturidiliğin Türkler arasında, Hanefiliğin de ülke genelinde yayılmasını arttırdığı gibi, Şafii-Hanefî farklılı̆̆ını hızlandırmışıır. Zamanla topluma hâkim olan "dört Sünni fikıh mezhebini meşru kabul etme" anlayışııın giderek yaygınlaşması ve kurumsallaşması sonucu, siyasi iktidarların bir mezhebin aleyhine faaliyetleri büyük ölçüde azalmıştır (Ünverdi, 2011: 38).

Türkiye'de Sünniliğin Hanefi ve Şafi mezheplerine mensup kişiler bulunmaktadır. Hanefî mezhebi, ismini, mezhebin metodolojisinin ve temel görüşlerinin oluşumunda önemli paya sahip Kufe'deki Re'y ekolünün öncülerinden olan Ebu Hanife'den almaktadır. Şafii mezhebi, özellikle İmam Şafii'nin hayatının son dönemini geçirdiği Mısır'da yayılmıştır. Osmanlıların Mısır'ı almasıyla birlikte, güç dengesi Hanefiliğin lehine değişmiştir. Bir dönem İran'da da etkili olan mezhep, zaman içerisinde bu ülkede yerini Şia'ya bırakmak zorunda kalmıştır. Günümüzde, Anadolu'nun doğu kesiminde, Kafkasya, Azerbaycan, Hindistan, Filistin, Seylan ve Malezya Müslümanları arasında Şafii mezhebine mensup olanlar bir hayli fazladır. Endonezya adalarında ise hâkim olan tek mezhep Şafii mezhebidir (Ünverdi, 2011: 18-30). Ancak hangi gerekçe ile olursa olsun, İslam tarihinde yaşanan mezhep kavgaları, daima Müslümanların aleyhine olmuş ve İslam medeniyetinin duraklamasına neden olmuştur.

\subsection{Tarihsel Süreçte Anadolu'da Alevi ve Sünni Mezhepleri}

Farklı renk, dil ve ırklardan oluşan insanların farklı görüşlere ve inançlara sahip olması tabii bir durumdur. Bu farklılıkları doğal kabul eden İslam ve Hz. Peygamber söz konusu özellikleri 'Müslüman' üst kimliğinde birer zenginlik olarak telakki etmiştir (Üçer, 2005: 13). XIV yy. başlarında Osmanlı henüz bir uç beyliği iken Selçuklu dönemindeki dinitasavvufi yapısının etkisiyle bu süfiyane anlayışı bünyesinde barındırdığı bilinmektedir (Üçer, 2005: 160).

Alevi ve Sünni kültürlerinin ilişkileri Osmanlı ve Safevi devletlerinin arasında yaşanan savaşlar ve çekişmeler nedeniyle olumlu yönde gelişmemiştir. Şah İsmail'in Tebriz'deki konumunu sağlamlaştırmasından sonra (İran'da yürüttüğü faaliyetlere ek olarak) kendisine bağlılıklarını sürdüren pek çok müridinin yaşadığı Anadolu topraklarında da 
yoğun bir propaganda faaliyeti sürdürmüştür. Anadolu'daki müritlerinin bu bağl1lıkları o dönem Anadolu'nun içinde bulunduğu siyasi ve sosyal ortam gereği daha da artırmıştır.

Orta Asya ve havalisinden Anadolu'ya yapılan göçler, Safevilerin etkisiyle aksi istikamete, yani Anadolu'dan İran'a yapılmaya başlanmıştır. Bu göçlerle İran'a giden grupların Safevi Devleti'nin kuruluşunda etkin rol aldıkları bilinmektedir. Safevilerin kurulmasına yardım eden bazı oymakların olduğu; bunlardan Hınıslı ve Çemişgezekli oymakların Erzurum'un güneyi ve Tunceli bölgesinde oturdukları bilinmektedir (Üçer, 2005: 167-168). Safevi devletinin Anadolu ile irtibatı daha eski olsa da Osmanlılar ile arasındaki resmi ilişkilerin Şeyh Safiyüddin'in altıncı batından torunu olan İsmail'in 1501'de Tebriz'de şahlığını ilan etmesiyle başladığını söylemek mümkündür. Ancak ilişkiler Şah İsmail'in Anadolu'ya yönelik faaliyetlerinin Osmanlı hâkimiyeti için açık tehdit içermesi nedeniyle olumsuz bir havada başlamış ve gelişmiştir. Taraflar asırdan süren ilişkiler içerisinde pek çok kez savaştıkları bilinmektedir.

1639'daki Kasr-1 Şirin Anlaşması Osmanlı-Safevi ilişkilerine uzun süreli bir sükûnet getirmiştir. İki devlet arasındaki barış süreci, 1772'de Afganlıların İran'a girmesiyle bozulma dönemine girmiştir. Türk tarihinde yeterli ilgiyi görmeyen Osmanlı-Safevi münasebetlerine dair yapılan çalışmaların büyük bir kısmı, Amasya Antlaşması'na kadar olan dönemi kapsar ve genellikle ilişkilerin siyasi-askeri seyrine odaklanır. Bununla birlikte çalışmalarda genel olarak öne çıkan husus mücadelenin mezhep ayrılı̆̆ından kaynaklanan bir durum olduğudur. İlk dönemler için mezhep ayrılığının çatışmaya yol açtı̆̆ fikri doğru olsa da, yaklaşık yüz elli yıl devam eden bir savaş sürecini sadece bu nedene dayandırmak yeterli değildir. Zira Osmanlı-Safevi mücadelesi salt Sünni-Şii karşıtllğından öte iç ve dış dinamiklerin, bölgesel çeşitliliklerin, uluslararası ittifakların ve jeopolitik kaygıların daha etkili olduğu bir mücadeledir.

Mezhep ayrılığı şüphesiz Osmanl1-Safevi münasebetlerinde belirleyici faktörlerden birisiydi. Bununla beraber akademik tarihçiliğin odaklandığı konuların Sünni-Şii çatışmasından ziyade Safevilerin Anadolu topraklarında yürüttükleri propaganda faaliyetleri ve yol açtığı sorunlardır. Bilhassa Osmanlı merkezi idaresinin Safevi Şiiliğini benimseyen ve on iki dilimli kızıl taç ve kızıl sarık giymeleri nedeniyle 'Kızılbaş' olarak adlandırılan kesime karşı uyguladığı sert siyaset mezhepsel bölünmeye önemli oranda etki etmiş̧ir. Öte yandan uzun süreli takibat ve cezalandırma siyasetinin etkileri günümüzde de hissedilecek şekilde Alevilerin giderek Sünni toplumdan dışlanmalarına ve devletten uzaklaşmalarına neden olmuştur. Günümüzde akademik tarihçilik kadar popüler tarihçiliğinin de ilgisini çekek konuma gelen Alevilik-Bektaşilik sorunsalı üzerine bilimsel çalışmalara artması olumlu bir gelişme olacaktır (Küpeli, 2010: 17-19).

Cumhuriyet dönemine bakıldığında ise Alevi ve Sünni ilişkilerinin 1938 Dersim olayları ile birlikte gerilim sürecine girdiği görülür. Daha sonra gelişen Çorum, Sivas ve Maraş olayları ile Alevi ve Sünni iletişiminin olumsuz yönde etkilendiği, ancak günümüzde iki inanış ve kültürün daha iyi ilişkiler içerisinde oldukları gözlemlenmektedir.

\subsection{Alevi-Sünni Dikotomisi}

Sünni-Alevi ilişkilerine bakıldığında iki grup arasındaki iletişimin tarihten günümüze değin sağlıklı bir biçimde gelişmediği görülmektedir. Özellikle Osmanlı devleti 
döneminde Alevi-Sünni inanışa mensup gruplar arasındaki iletişimlerin ve diyalogların temelde siyasi odaklı gerilimler nedeniyle olumlu yönde seyretmediğini söylemek mümkün görünmektedir. Osmanl1-Safevi devletleri arasındaki siyasi mücadelelerin bu durumu önemli ölçüde etkilediği bilinmektedir. Günümüzde ise bu iki inanış arasında bazı sorunların hala varlığını sürdürdüğü görülmektedir. Özellikle Alevi toplumuyla ilgili 'mum söndü', 'gusülsüz' gibi ithamların bulunması ayrılıklara ve gerilimlere örnek gösterilebilir. Bu arada siyasi farklılıkların da önemli sorunlardan biri olduğunu söylemek mümkün görünmektedir. Dolayısıyla iki inanış arasındaki gerilimlerin altında siyasi mülahazaların baskın ve başat rol oynadığı söylenebilir. Alevilerin daha çok sol ve sosyalist siyasi akımların içinde olmaları; 'Marksist', 'Ateist', 'Komünist' veya 'Kızıllar' gibi nitelendirilmelerine sebebiyet verirken, Sünnilerin ise daha çok sağ ve muhafazakâr hareketler içinde bulunmaları; 'Gerici', 'Yobaz', 'Milliyetçi' veya 'Ülkücü' ş̧eklinde tanımlanmalarına neden olmaktadır.

Ayrıca yakın tarihte Maraş, Çorum ve Sivas gibi hafızalarda yer tutan olaylarda Alevilerin katliama maruz kaldıkları veya mağdur edildiklerine yönelik algılar da iki inanış arasındaki gerginliklere örnek gösterilebilir. Diğer taraftan aralarındaki kültür ve temel ibadet farklılıkları da birbirlerine karşı mesafeli durmalarına yol açabilmektedir. Yine evlilikler konusunda her iki toplumun muhalif refleks sergilemeleri de bir hipotez olarak dillendirilebilir. Ancak her şeye rağmen son dönemlerde özellikle gençlerin evliliğe daha olumlu baktıkları gözlemlenmektedir. Zira yapılan bazı bilimsel verilere ve gözlemlere bakıldığında ön yargılara rağmen her iki toplumun aynı ortamlarda bulunmaktan imtina etmedikleri, aynı okullarda okudukları, arkadaşlık ve komşuluk ilişkileri içerisinde oldukları tespit edilmiştir. Diğer bir ifadeyle aralarındaki kültürel ve ibadet farklılıklarına ve tarihsel süreçteki olumsuz olaylara karşın her iki toplumun da birbirleriyle iletişime açık ve gönüllü oldukları söylenebilir.

\section{VERI SETI, METODOLOJI VE UYGULANAN ISTATIKSEL YÖNTEM}

\subsection{Araştırma}

\subsubsection{Problem Durumu}

Sosyal bilimlerle uğraşmak sıradan bir bilgi edinme süreci değildir (Giddens'den aktaran Özmen, 2006: 21) ve sosyal bilimciler ilgilendikleri konuları sıradan ve toplumsal sorunlardan bağımsız ölçütlerle seçme özgürlüğüne sahip değillerdir. Sosyal bilimcilerin seçtikleri konular, içinde yaşadıkları toplumsal tarihten ve buna gösterdikleri kişisel duyarlılıklardan bağımsız olmamalıdır (Göle'den aktaran Özmen, 2006: 21). Bu açıdan içinde yaşanılan toplumun sorunlarına duyarlı bir yaklaşımın benimsendiği bir bilimsel refleks, sosyal bilimlerin de özüne daha yatkın görünmektedir (Özmen, 2006: 21).

$\mathrm{Bu}$ Araştırma var olduğu ön görülen bu tür sosyal sorunları, özellikle Alevi ve Sünni kültürleri özelinde test etmeye yöneliktir. $\mathrm{Bu}$ bağlamdan hareketle şu sorula cevap aranarak alt problemler analiz edilmeye çalışılmıştır: İki kültürün bir birleri hakkında yanlış görüşleri var mıdır? Aralarındaki farklı siyasi görüş ve düşüncelere dayalı çatışmalar iletişimlerinde etkin midir? Alevi ve Sünni evliliğine taraflar nasıl 
bakmaktadır? Bu grupların Alevilik, Sünnilik ve Müslümanlık hakkındaki düşünceleri ne yöndedir? Aralarındaki sosyal ilişkiler nasıldır?

\subsubsection{Amaç}

Alevi ve Sünni mezhepleri yıllardan beri Anadolu topraklarında birlikte yaşamışlar ve karşılıklı olarak etkileşimde bulunmuşlardır. Bu iki kültür geçmişten günümüze dek farklı alanlarda birbirleriyle iletişim kurmuşlardır. Aralarında olumsuz yönde gelişen iletişimin ve ilişsilerin sebebi karşılıklı olarak oluşturulan önyargılardır denilebilir. Örneğin Alevilik hakkında bilinen en önemli önyargılardan biri 'mum söndü' hadisesidir. Ancak günümüzde bu algının ortadan kalktığ 1 görülmektedir. Aynı durum Aleviler tarafından Sünnilik inancına dair oluşturulan algılar için de geçerlidir. Zira bilgiye ulaşıldıkça, okuyan ve araştıran bireylerin sayısı arttıkça bu tür algıların yersiz ve yanlış olduğu ortaya çıkmaktadır.

Diğer taraftan sanayileşme ve kentleşmeyle birlikte kırsalda kapalı toplum şeklinde yaşayan Alevi ve Sünnilerin metropollere göçü ile birlikte Alevi ve Sünni toplumlar birbirine komşu veya mesai arkadaş olmak zorunda kalmıştır. Böylelikle aralarında bir iletişim ve etkileşim süreci oluşmuş, diyalog doğrudan sağlanmaya başlanmış ve tabuların yıkılması kaçınılmaz hale gelmiştir denilebilir. Ancak bazı metropoller de Alevi ve Sünni toplumlarının belirli bölgelerde kümelenmeleri, kendi mahallelerini ve sokaklarını oluşturmaları kapalı toplum düzeninin devamına neden olabilmektedir. $\mathrm{Bu}$ durum zaman zaman iki toplum arasında iletişim kopukluğuna neden olmakta ve toplumsal çatışmalara yol açabilmektedir. Kuşkusuz bu çatışmaların çoğunluğu mezhepsel olmaktan öte siyasal çatışmalardır. Tüm bu bilgiler 1şı̆̆ında bu araştırmanın amacı; Türkiye'de (Tunceli ve Elazı̆̆ ili özelinde) Alevi ve Sünni inanışlarının etkileşimini, önyargılara ilişkin kanaatlerini ve iletişimlerini ortaya koymaktır.

\subsection{3. Önem}

Türkiye'de mezhep bağlamında Alevi ve Sünni kültürlerinin iletişimlerine yönelik alan araştırmalarının tatmin edici düzeyde olmadığı ve tekrarlanabilir özellik taşıyan bu tür bilimsel verilere dayalı çalışmaların yetersiz olduğu bilinmektedir. Alevi-Sünni iletişimine yönelik araştırmalar daha ziyade kültürel ve teolojik açıdan ele alınmaktadır. Alevi-Sünni inanışları arasında yaşanan algısal sorunlara ve çatışmalara yer verilmemektedir. Konunun güncel verilerle desteklenmesi şüphesiz bu alana önemli ölçüde katkı sağlayacaktır. Dolayısıyla Alevi-Sünni inanışları arasındaki iletişımin boyutunu ortaya koyacak olması açısından bu araştırma önem arz etmektedir.

\subsubsection{Hipotezler}

“Kültürlerarası İletişim Bağlamında Alevi-Sünni Dikotomisi (Tunceli ve Elazı̆̆ İlleri Örneklemi İle Mezheplerarası İletişim ve Etkileşim” başlı̆̆ı ile yürütülen bu araştırmada şu hipotezlerden hareket edilmiştir:

(i) Denekler kendi inanışlarını bir mezhep olarak tanımlarlar, 
(ii) Denekler karşı inanç mensupları tarafından kendilerine ayrımcılık yapılmasını itici unsur olarak değerlendirirler,

(iii) Denekler karşı inanç mensuplarını Alevi veya Sünni şeklinde tanımlarlar,

(iv) Denklerin karşı inanış mensuplarından beklentileri kendilerine hoşgörülü olmalarıdir,

(v) Denekler Alevilik ile Sünnilik arasında bir farklılık görmezler,

(vi) Denekler, inanışlarının bir mezhebi çağrıştırdığı kanaatini taşırlar,

(vii) Denekler karşı inanç mensupları ile daha çok kutsal bayramlarda bir araya gelmeye çalışırlar,

(viii) Denekler karşı inanç mensuplarıyla daha çok alış-veriş ortamlarında etkileşim ve iletişim içerisinde olurlar,

(ix) Denekler karşı inanç mensuplarıyla evliliğe olumlu bakarlar,

(x) Denekler Alevi-Sünni bütünleşmesinin gerekliliğine inanırlar,

(xi) Denekler karşı inanışın baskın olduğu ortamlarda mezhebi aidiyetlerini rahatlıkla söyleyebilirler.

\subsection{Yöntem}

\subsubsection{Araştırma Modeli}

Bu araştırmada bilimsel yöntem olarak Survey modeli uygun bulunmuş ve yöntem gereği anket tekniğine başvurulmuştur. Anket, öngörülen koşullar çerçevesinde (75 bin kişi ile 1 milyon nüfuslu yerleşim yerleri için öngörülen) en az 384 deneğe uygulanmıştır (Krejcie and Morgan 1970: 607-610). Bu yöntem ile Elazığ ve Tunceli illeri arasındaki (mezhepsel açıdan) inanç algısına, çatışmasına ve ötekileştirme kaygılarına yönelik korelasyon bilimsel verilere dayalı olarak ölçülmeye ve test edilmeye çalışılmıştır. Buradaki temel amaç iki inanç kültürünün iletişimlerini derinlemesine araştırmak ve iletişimleri hakkında bilimsel verilere ulaşmaktır. Araştırmanın örneklem gruplarını, şehir merkezleri oluşturmaktadır. Anket uygulaması için random yöntemi uygun bulunmuş ve tabakalama yöntemi gereğince katılımcılar rastgele seçilmiştir (Kaptan, 1993: 120-122).

\subsubsection{Evren, Örneklem, Sinırlılıklar ve Kapsam}

Araştırmanın evrenini Türkiye oluşturmaktadır. Her iki inanışın Türkiye genelinde heterojen bir dağılım gösterdiği bilinmektedir. Dolayısıyla araştırmanın genellenebilirliği açısından Türkiye everen olarak belirlenmiştir. Ancak çalışma için Tunceli ve Elazı ğ illeri örneklem olarak seçilmiştir. Tunceli ilinde özellikle Alevi, Elazı̆̆ ilinde ise Sünni vatandaşların yoğunluklu olması demografik açıdan bu illerin örneklem seçilmesinin temel nedenidir. Araştırmanın Tunceli ve Elazı̆̆ il merkezleriyle sınırlı tutulması ve anket uygulamasının eşzamanlı olarak yürütülmesi ise araştırmanın sınırlılıkları olarak belirlenmiştir. 


\subsubsection{Anket Uygulaması, Verilerin Toplanması ve Analizi Yöntemi}

Anketler Tunceli ve Elazığ illeri merkezlerinde anket sayısı eşit şekilde ikiye bölünerek $(192+192=384$ şeklinde) uygulanmıştır. Anket uygulaması şehir merkezlerinde vatandaşlarla yüz yüze görüşme tekniğiyle yürütülmüştür. Anketin objektif biçimde uygulanabilmesi ve sonuçlarının nesnel olarak değerlendirilebilmesi için vatandaşlardan kimlik bilgileri istenmemiştir. Çalışma, rastgele (random) örnekleme yöntemi kullanılarak ulaşılan 384 denek üzerinde yapılmıştır. Elde edilen veriler bilgisayar ortamında SPSS 16,0 sürümü kullanılarak değerlendirilmiştir. Hataların engellenebilmesi ve soruların anlaşılabilirliğinin test edilmesi amacıyla anket formu, öncelikle beş kişilik bir denek grubuna uygulanarak ön test yapılmış ve tespit edilen hatalar düzeltilerek genele uygulamıştır.

\subsection{Verilerin Çözümü}

\subsubsection{Verilerin Analizi}

Bu araştırma için örneklem olarak Tunceli ve Elazığ illeri belirlenmiştir. Bu illerin tercih nedeni; her iki ilin aynı coğrafi konumda ve birbirlerine komşu il olmalarına rağmen farklı inanış ve mezhep anlayışının (Alevi-Sünni) baskın olmasıdır. Dolayısıyla bu çalışma için en sağlıklı ve nesnel verilerin bu illerden toplanabileceği düşüncesi bu tür bir örneklem seçiminin nedeni olarak gösterilebilir. Bu bağlamda Tunceli ilinde 192 ve Elazığ ilinde 192 olmak üzere 384 deneğe random yöntemi ile anket uygulanmıştır.

Tablo 1. Elazı ̆̆ İlinin Demografik Bulguları

\begin{tabular}{lcccccccccccc}
\hline & \multicolumn{2}{c}{$\mathrm{a}$} & \multicolumn{2}{c}{$\mathrm{b}$} & \multicolumn{2}{c}{$\mathrm{c}$} & \multicolumn{2}{c}{$\mathrm{d}$} & \multicolumn{2}{c}{$\mathrm{e}$} & \multicolumn{2}{c}{ Toplam } \\
\hline & $\mathrm{f}$ & $\%$ & $\mathrm{f}$ & $\%$ & $\mathrm{f}$ & $\%$ & $\mathrm{f}$ & $\%$ & $\mathrm{f}$ & $\%$ & $\mathrm{f}$ & $\%$ \\
\hline Cinsiyet & 89 & 46.4 & 103 & 53.6 & & & & & & & 192 & 100 \\
Yaş & 26 & 13.5 & 41 & 21.4 & 55 & 28.6 & 51 & 26.6 & 19 & 9.9 & & \\
Eğitim & 14 & 7.3 & 24 & 12.5 & 74 & 38.5 & 80 & 41.7 & & & 192 & 100 \\
Mezhep & 105 & 54.7 & 87 & 45.3 & - & - & - & - & & & 192 & 100 \\
\hline
\end{tabular}

Tablo 2. Tunceli İlinin Demografik Bulguları

\begin{tabular}{lcccccccccccc}
\hline & \multicolumn{2}{c}{$\mathrm{a}$} & \multicolumn{2}{c}{$\mathrm{b}$} & \multicolumn{2}{c}{$\mathrm{c}$} & \multicolumn{2}{c}{$\mathrm{d}$} & \multicolumn{2}{c}{$\mathrm{e}$} & \multicolumn{2}{c}{ Toplam } \\
\hline & $\mathrm{f}$ & $\%$ & $\mathrm{f}$ & $\%$ & $\mathrm{f}$ & $\%$ & $\mathrm{f}$ & $\%$ & $\mathrm{f}$ & $\%$ & $\mathrm{f}$ & $\%$ \\
\hline Cinsiyet & 91 & 47.4 & 101 & 52.6 & & & & & & & 192 & 100 \\
Yaş & 98 & 51.0 & 46 & 24.0 & 29 & 15.1 & 9 & 4.7 & 10 & 5.2 & & \\
Ĕ̆itim & 17 & 8.9 & 16 & 8.3 & 120 & 62.5 & 39 & 20.3 & & & 192 & 100 \\
Mezhep & 4 & 2.0 & 161 & 84.0 & 27 & 14.0 & - & - & & & 192 & 100 \\
\hline
\end{tabular}


Tablo 3. Deneklerin Demografik Bulgularının Genel Dağılımı

\begin{tabular}{lcccccccccccc}
\hline & \multicolumn{2}{c}{$\mathrm{a}$} & \multicolumn{2}{c}{$\mathrm{b}$} & \multicolumn{2}{c}{$\mathrm{c}$} & \multicolumn{2}{c}{$\mathrm{d}$} & \multicolumn{2}{c}{$\mathrm{e}$} & \multicolumn{3}{c}{ Toplam } \\
\hline & $\mathrm{f}$ & $\%$ & $\mathrm{f}$ & $\%$ & $\mathrm{f}$ & $\%$ & $\mathrm{f}$ & $\%$ & $\mathrm{f}$ & $\%$ & $\mathrm{f}$ & $\%$ \\
\hline Cinsiyet & 180 & 46.9 & 204 & 53.1 & & & & & & & 384 & 100 \\
Yaş & 124 & 32.3 & 87 & 22.6 & 84 & 21.9 & 60 & 15.6 & 29 & 7.6 & 384 & 100 \\
Eğitim & 31 & 8.1 & 40 & 10.4 & 194 & 50.5 & 119 & 31.0 & & & 384 & 100 \\
Mezhep & 109 & 28.4 & 248 & 64.6 & 27 & 7.0 & - & - & & & 384 & 100 \\
\hline
\end{tabular}

$\begin{array}{llllll}\text { Cinsiyet } & \text { : a- Erkek } & \text { b- Kadın } & & & \\ \text { Yaş } & : \text { a- 15-18 } & \text { b- 19-25 } & \text { c- 26-35 } & \text { d- 36-50 } & \text { e- 51 ve üzeri } \\ \text { Eğitim } & : \text { a- Okur-Yazar değil } & \text { b- ̇̇lköğretim } & \text { c- Lise } & \text { d- Üniversite } & \\ \text { Mezhep } & : \text { a- Sünni } & \text { b- Alevi } & \text { c- Mezhepsiz } & \text { d- Diğer } & \end{array}$

Yukarıdaki verilere göre; Elazığ ilinde ankete iştirak eden kadınların oranı \% 53,6; erkeklerin oranı 46,4'tür. Tunceli'de ise kadınların oranı $\% 52,6$; erkeklerin ise $\%$ 47,4'tür. Bu veriler, ulaşılan katılımcılar açısından hem cinsiyetlere hem de illere göre paralellik arz etmektedir. Elde edilen verilere bakıldığında Elazığ ilinde ankete katılan deneklerin yaş aralığında dengeli bir dağılım olduğu görülürken, Tunceli ilinde yaş aralığının ağırlıklı olarak \% 51,0 ile 15-18 gurubundan oluştuğu görülmektedir. Deneklerin illere göre eğitim durumlarına ilişkin karşılaştırmalı verilerine bakıldığında; ulaşılan deneklerin eğitim durumları ağırlıklı olarak Lise ve Yükseköğretim düzeyindedir. Ancak Tunceli ilindeki deneklerin ağırlıklı olarak (\% 62,5) Lise, buna karşın Elazığ ilinde ise (\% 41,7) Yükseköğretim mezunlarından oluştuğu görülmektedir. Elazığ ilinde yapılan anket uygulamasında; deneklerin \% 54,7'si Sünni, \% 45,3'ünün ise Alevi oldukları, Tunceli ilinde ise deneklerin \% 83,9'u Alevi oldukların beyan ederken sadece \% 1,6'sı Sünni olduklarını ifade etmişlerdir. Genel duruma bakıldığında ise ankete katılan deneklerin \% 28,4'ünün Sünni ve \% 64,6'sının ise Alevi olduğu tespit edilmiştir. Ortalama bir değere ulaşılamamış olmasının nedeni Elazığ'ın demografik yapısının Tunceli'ye nazaran daha heterojen olmasına dayandırılabilir.

Tablo 4. Elazığ'daki Deneklerin Sünniliği, Tunceli'deki Deneklerin ise Aleviliği Nasıl Tanımladıklarına İlişkin Görüşleri

\begin{tabular}{lcccccc}
\hline & \multicolumn{2}{c}{ Elazı̆ } & \multicolumn{2}{c}{ Tunceli } & \multicolumn{2}{c}{ GENEL } \\
\cline { 2 - 7 } & $\mathrm{f}$ & $\%$ & $\mathrm{f}$ & $\%$ & $\mathrm{f}$ & $\%$ \\
\hline Din & 33 & 17.2 & 62 & 32.3 & 95 & 24.7 \\
Mezhep & 144 & 75.0 & 91 & 47.4 & 235 & 61.2 \\
Öğreti/Felsefe & 13 & 6.8 & 23 & 12.0 & 36 & 9.3 \\
Tarikat & 2 & 1.0 & 14 & 7.3 & 16 & 4.3 \\
Diğer & - & & 2 & 1.0 & 2 & 0.5 \\
Toplam & 192 & 100 & 192 & 100 & 384 & 100 \\
\hline
\end{tabular}

Elde edilen verilere bakıldığında Elazığ'da ulaşılan katılımcıların \%75'i Sünniliği 'bir mezhep', \% 17,2'si ise 'bir din' olarak görmektedirler. Buna karşın Tunceli ilinde ulaşılan deneklerin ise \% 47,4'ü Aleviliği 'bir mezhep', \% 32,3'ü ise 'bir din' olarak görmektedirler. Genel değerlendirmeye bakıldığında; anket uygulamasına iştirak eden deneklerin \% 61,2'sinin mensubu bulundukları inanışı bir mezhep, \% 24,7'sinin ise bir din olarak değerlendirdiklerini söylemek mümkün görünmektedir. 
Tablo 5. Elazı̆̆ ilindeki Deneklerin Alevi Olanlarda, Tunceli İlindeki Deneklerin ise Sünni Olanlarda En İtici Buldukları Yönlerinin Ne Olduğuna Dair Bulgular

\begin{tabular}{|c|c|c|c|c|c|c|}
\hline & \multicolumn{2}{|c|}{ Elazı̆̆ } & \multicolumn{2}{|c|}{ Tunceli } & \multicolumn{2}{|c|}{ GENEL } \\
\hline & $f$ & $\%$ & $\mathrm{f}$ & $\%$ & $\mathrm{f}$ & $\%$ \\
\hline $\begin{array}{l}\text { Mezhepleriyle ilgili yanlış } \\
\text { inanışları }\end{array}$ & 62 & 32.3 & 79 & 41.1 & 141 & 36.7 \\
\hline İslamiyet'i farklı yaşamaları & 94 & 49.0 & 33 & 17.2 & 127 & 33.1 \\
\hline $\begin{array}{l}\text { Sünni olmamaları/Alevilere yapılan } \\
\text { ayrımcılık }\end{array}$ & 36 & 18.8 & 80 & 41.7 & 116 & 30.2 \\
\hline Toplam & 192 & 100 & 194 & 100 & 384 & 100 \\
\hline
\end{tabular}

Elazı ̆̆ ilinde ulaşılan deneklerin görüşlerine göre Alevilerin en itici yönü (\% 49) “Íslamiyet'i farklı yaşamaları"dır. Buna karşın Tunceli ilindeki deneklerin ise Sünnilerde en itici buldukları unsur (\% 47,7) kendilerine “(Alevilere) yapılan ayrımcılık”tır. Ancak Sünnilerin "Alevilikle ilgili yanlış inanışları"da dikkat çekmektedir diğer önemli bir bulgudur.

Tablo 6. Deneklerin Sünni - Alevi Olmayanları Nasıl Tanımladıklarına ilişkin Görüşleri

\begin{tabular}{lcccccc}
\hline & \multicolumn{2}{c}{ Elazı $\breve{c}$} & \multicolumn{2}{c}{ Tunceli } & \multicolumn{2}{c}{ GENEL } \\
\cline { 2 - 7 } & $\mathrm{f}$ & $\%$ & $\mathrm{f}$ & $\%$ & $\mathrm{f}$ & $\%$ \\
\hline Alevi / Sünni & 46 & 24.0 & 75 & 39.1 & 121 & 31.5 \\
Dinsiz / Dinci & 14 & 7.3 & 45 & 23.4 & 59 & 15.4 \\
Müslüman & 99 & 51.5 & 34 & 17.7 & 133 & 34.6 \\
Alevi / Sünni Müslüman & 33 & 17.2 & 25 & 13.0 & 58 & 15.1 \\
Diğer & - & - & 13 & 6.8 & 13 & 3.4 \\
Toplam & 192 & 100 & 192 & 100 & 384 & 100 \\
\hline
\end{tabular}

Elde edilen verilere bakıldığında Elazı ̆̆ ilindeki deneklerin Sünni olmayanları $(\% 51,5)$ 'Müslüman' şeklinde tanımlandıkları görülmektedir. Bununla beraber 'Alevi' veya 'Alevi Müslüman' yanıtları da dikkat çekmektedir. Buna karşın Tunceli ilinde ise katılımcılar Alevi inanışından olmayanları \% 39,1'lik oranda 'Sünni' ve \% 23,4 oranında ise 'Dinci' olarak tanımladıkları tespit edilmiştir.

Tablo 7. Deneklerin Farklı İnanış Mensupları Olarak Birbirlerinden Beklentileri

\begin{tabular}{lcccccc}
\hline & \multicolumn{2}{c}{ Elazı̆̆ } & \multicolumn{2}{c}{ Tunceli } & \multicolumn{2}{c}{ GENEL } \\
\cline { 2 - 7 } & $\mathrm{f}$ & $\%$ & $\mathrm{f}$ & $\%$ & $\mathrm{f}$ & $\%$ \\
\hline Hoşgörü & 84 & 43.8 & 38 & 19.8 & 122 & 31.8 \\
Eşitlik & 32 & 16.7 & 67 & 34.9 & 99 & 25.8 \\
Sünnilik/Alevilik ile ilgili yanlış & 73 & 38.0 & 81 & 42.2 & 154 & 40.1 \\
yargıları terk & 3 & 1.5 & 6 & 3.1 & 9 & 2.3 \\
Diğer & 192 & 100 & 192 & 100 & 384 & 100 \\
Toplam & & & & &
\end{tabular}

Elazı̆̆ ilindeki deneklerin farklı inanış mensubu olarak gördükleri Alevilerden beklentileri ağırlıklı olarak (\% 43,8) 'Hoşgörü', buna karşın Tunceli ilindeki deneklerin ise Sünnilerden beklentileri (\% 42,2) 'Alevilikle ilgili yanlış inanışları terk etme'dir. Tunceli ilinde anket uygulamasına iştirak eden deneklerin diğer bir beklentisi olan 'Eşitlik' seçeneği de (\% 34,9) dikkat çekmektedir. Genel olarak değerlendirildiğinde ise 
her iki ildeki deneklerin karşı inanıştan ağırlıklı olarak (\% 40,1) "Sünnilik veya Alevilik ile ilgili yanlış yarglları terk etme" beklentisi içerisinde oldukları sonucuna ulaşılmıştır.

Tablo 8. Alevilik ile Sünnilik Arasında Ayrılık Olup Olmadığına İlişkin Bulgular

\begin{tabular}{lcccccc}
\hline & \multicolumn{2}{c}{ Elaziğ } & \multicolumn{2}{c}{ Tunceli } & \multicolumn{2}{c}{ GENEL } \\
\cline { 2 - 7 } & $\mathrm{f}$ & $\%$ & $\mathrm{f}$ & $\%$ & $\mathrm{f}$ & $\%$ \\
\hline Evet & 81 & 42.2 & 100 & 52.1 & 181 & 47.1 \\
Hayır & 111 & 57.8 & 92 & 47.9 & 203 & 52.9 \\
Toplam & 192 & 100 & 194 & 100 & 384 & 100 \\
\hline
\end{tabular}

Elde edilen bulgulara göre Elazığ ilindeki katılımcılar ağırlıklı olarak (\% 57,8 oranında) Alevilik ile Sünnilik inancı arasında bir fark görmemektedirler. Tunceli ilindeki deneklerin ise (\% 52,1 oranında) Alevi inanış1 ile Sünnilik arasında bir fark olduğunu beyan etmişlerdir. Ancak \% 47,9 gibi bir oranın fark olmadığına yönelik görüş belirtmeleri dikkat çekmektedir. Genel değerlendirmeye bakıldığında ise Alevilik ile Sünnilik arasında bir ayrılık olup olmadığına dair deneklerin görüşlerinin dağılımında oransal olarak bir eşitliğin olduğunu söylemek mümkün görünmektedir.

Tablo 9. Alevi ve Sünni Kavramların Neyi Çağrıştırdığına Dair Deneklerin Görüşleri

\begin{tabular}{lcccccc}
\hline & \multicolumn{2}{c}{ Elazı̆ } & \multicolumn{2}{c}{ Tunceli } & \multicolumn{2}{c}{ GENEL } \\
\cline { 2 - 7 } & $\mathrm{f}$ & $\%$ & $\mathrm{f}$ & $\%$ & $\mathrm{f}$ & $\%$ \\
\hline Kur'an'a/Sünnete bağlı bir şeriat anlayışı & 13 & 6.8 & 59 & 30.7 & 72 & 18.7 \\
İslami bir mezhep & 41 & 21.4 & 93 & 48.5 & 134 & 34.9 \\
Hz. Ali ve Ehlibeyt taraftarı/karşıtı olma & 138 & 71.9 & 40 & 20.8 & 178 & 46.4 \\
Toplam & 192 & 100 & 192 & 100 & 384 & 100 \\
\hline
\end{tabular}

Elazığ ilinde ankete katılan deneklerin \% 71,9’u Aleviliği ' $H z$. Ali ve Ehlibeyt taraftarl olma' şeklinde tanımlamaktadırlar. Buna karşın Tunceli ilinde ise katılımcılar (\% 48,5 oranında) Sünniliği daha ziyade 'Íslami bir mezhep' olarak görmektedirler. Ancak 'Kuran'a ve sünnete bağlı bir şeriat anlayışı' seçeneği de (\% 30,7'lik oranla) dikkat çekmektedir.

Tablo 10:Deneklerin Sünni-Alevi Olmayanlarla Hangi Ortamlarda Daha Çok İlişki İçerisinde Olduklarına İlişkin Görüşleri

\begin{tabular}{lcccccc}
\hline & \multicolumn{2}{c}{ Elazı̆ } & \multicolumn{2}{c}{ Tunceli } & \multicolumn{2}{c}{ GENEL } \\
\cline { 2 - 7 } & $\mathrm{f}$ & $\%$ & $\mathrm{f}$ & $\%$ & $\mathrm{f}$ & $\%$ \\
\hline Kutsal bayramlarda & 25 & 13.0 & 28 & 14.7 & 53 & 13.8 \\
Ticaret ve alışveriş̧te & 138 & 71.9 & 73 & 38.0 & 211 & 55.0 \\
Ulusal bayramlarda & 8 & 4.2 & 60 & 31.2 & 68 & 17.7 \\
Diğer & 21 & 10.9 & 31 & 16.1 & 52 & 13.5 \\
Toplam & 192 & 100 & 192 & 100 & 384 & 100 \\
\hline
\end{tabular}

Sünni olmayanlarla hangi ortamlarda daha çok ilişki ve iletişim içerisinde olduklarına ilişkin Elazı ̆̆ ilindeki deneklerin görüşlerine bakıldığında \% 71,9'luk oranla 'ticaret ve alış-veriş' seçeneğinin baskın olarak ön plana çıktığı görülmektedir. Tunceli ilinde de yine deneklerin \% 38,0'lık oranla aynı seçeneği önemsedikleri tespit edilmiştir. Tunceli ilinde dikkat çeken diğer bir seçenek ise (\% 31,2'lik oranda) 'ulusal bayramlar'dır. Burada öne çıkan en öneli husus; her iki ilde de kutsal (dini) bayramların düşük 
çıkmasıdır. Bu durum, temel ayrışma noktası olarak düşünülebilir. Ancak genel verilere bakıldığında da "ticaret ve alış-veriş" seçeneğinin baskın olduğu görülmektedir.

Tablo 11. Deneklerin Sünni-Alevi olmayanlarla hangi alanda daha fazla etkileşim ve İletişim İçerisinde Olduklarına Dair Görüşleri

\begin{tabular}{lcccccc}
\hline & \multicolumn{2}{c}{ Elazı̆ } & \multicolumn{2}{c}{ Tunceli } & \multicolumn{2}{c}{ GENEL } \\
\cline { 2 - 7 } & $\mathrm{f}$ & $\%$ & $\mathrm{f}$ & $\%$ & $\mathrm{f}$ & $\%$ \\
\hline Evlilikte & 17 & 8.9 & 15 & 7.9 & 32 & 8.3 \\
Eğitimde & 57 & 29.7 & 121 & 63.0 & 178 & 46.4 \\
Eğlencede & 49 & 25.5 & 24 & 12.5 & 73 & 19.0 \\
Alışverişte & 57 & 29.7 & 26 & 13.5 & 83 & 21.6 \\
Diğer & 12 & 6.2 & 6 & 3.1 & 18 & 4.7 \\
Toplam & 192 & 100 & 192 & 100 & 384 & 100 \\
\hline
\end{tabular}

Elde edilen verilere göre Elazığ ilindeki deneklerin 'eğitim', 'alış-veriş', ve 'eğlence' seçenekleri arasında eşit bir dağılımın olduğu görülmektedir. Bu oran yaklaşık \% 85'e tekabül etmektedir. Buna karşın Tunceli ilinde ise ağırlıklı olarak (\% 63,0) 'eğitim' alanının ön plana çıktığı tespit edilmiştir. Ancak 'evlilik' seçeneğinin her iki ilde de düşük oranda olması anlamlı bir bulgu olarak değerlendirilebilir. Genel bulgulara bakıldığında deneklerin Sünni-Alevi olmayanlarla 'eğitim' alanında daha fazla etkileşim ve iletişim içerisinde oldukları sonucuna ulaşıllmaktadır.

Tablo 12. Sünni-Alevi Olmayanlarla Evliliğe Nasıl Baktıklarına Dair Bulgular

\begin{tabular}{lcccccc}
\hline & \multicolumn{2}{c}{ Elazı̆ } & \multicolumn{2}{c}{ Tunceli } & \multicolumn{2}{c}{ GENEL } \\
\cline { 2 - 7 } & $\mathrm{f}$ & $\%$ & $\mathrm{f}$ & $\%$ & $\mathrm{f}$ & $\%$ \\
\hline Olumlu & 85 & 44.3 & 88 & 45.8 & 173 & 45.1 \\
Olumsuz & 40 & 20.8 & 37 & 19.3 & 77 & 20.0 \\
Kararsiz & 34 & 17.7 & 44 & 22.9 & 78 & 20.3 \\
Fikri olmayanlar & 33 & 17.2 & 23 & 12.0 & 56 & 14.6 \\
Toplam & 192 & 100 & 192 & 100 & 384 & 100 \\
\hline
\end{tabular}

Bir önceki tablodan da anlaşılacağı üzere Sünni ve Alevi inanışları arasında evlilik oranının düşük seviyelerde seyrettiği tespit edilmişti. Ancak deneklerin Sünni-Alevi olmayanlarla evliliğe nasıl baktıklarına yönelik sorudan elde edilen bulguların bu sonuçları teyit eder mahiyette olmadığı görülmüştür. Diğer bir anlatımla her iki ildeki katılımcılar karşı inanıştakiler ile evlilik ilişkisi içerisinde olmamalarına rağmen karşı inanıştakilerle evliliğe olumlu bakmaktadırlar denilebilir. Zira her iki ildeki deneklerin ortalama olarak (\% 45 oranında) karşı inanış ile evliliğe sıcak baktıkları sonucuna ulaşılmıştır.

Tablo 13. Deneklerin Alevi-Sünni Bütünleşmesinin Gerekliliğine Dair Görüşleri

\begin{tabular}{lcccccc}
\hline & \multicolumn{2}{c}{ Elazı̆ } & \multicolumn{2}{c}{ Tunceli } & \multicolumn{2}{c}{ GENEL } \\
\cline { 2 - 7 } & $\mathrm{f}$ & $\%$ & $\mathrm{f}$ & $\%$ & $\mathrm{f}$ & $\%$ \\
\hline Evet & 75 & 39.1 & 105 & 54.7 & 180 & 46.9 \\
Hayır & 27 & 14.0 & 40 & 20.8 & 67 & 17.4 \\
Kismen & 47 & 24.5 & 33 & 17.2 & 80 & 20.8 \\
Fikri olmayanlar & 43 & 22.4 & 14 & 7.3 & 57 & 14.9 \\
Toplam & 192 & 100 & 192 & 100 & 384 & 100 \\
\hline
\end{tabular}


Elde edilen verilere göre; her ildeki deneklerin ('klsmen' seçeneği ile oran \% 67,7'e ulaşılmaktadır) ağırlıklı olarak bir Sünni-Alevi bütünleşmesine ihtiyaç duyulduğunu beyan ettikleri görülmüştür. İl bazında değerlendirildiğinde bu düşüncenin özellikle Tunceli ilindeki deneklerde daha baskın olduğu (\% 54,7) sonucuna ulaşılmıştır.

Tablo 14. Deneklerin Karşı İnanışın Baskın Olduğu Ortamlarda Sünni-Alevi Olduklarını Rahatlıkla Söyleyip Söyleyemediklerine İlişkin Bulgular

\begin{tabular}{lcccccc}
\hline & \multicolumn{2}{c}{ Elazı $\breve{c}$} & \multicolumn{2}{c}{ Tunceli } & \multicolumn{2}{c}{ GENEL } \\
\cline { 2 - 7 } & $\mathrm{f}$ & $\%$ & $\mathrm{f}$ & $\%$ & $\mathrm{f}$ & $\%$ \\
\hline Evet & 127 & 66.1 & 99 & 51.0 & 226 & 58.8 \\
Hayır & 2 & 1.0 & 24 & 13.0 & 26 & 6.8 \\
Bazen & 38 & 19.8 & 46 & 24.0 & 84 & 21.9 \\
Fikri olmayanlar & 25 & 13.1 & 23 & 12.0 & 48 & 12.5 \\
Toplam & 192 & 100 & 192 & 100 & 384 & 100 \\
\hline
\end{tabular}

Elde edilen bulgulara göre karşı inanışın baskın olduğu ortamlarda deneklerin ağırlıklı olarak $(\% 58,8)$ inanışlarını rahatlıkla beyan ettikleri sonucuna ulaşılmıştır. Bu oran Elazı̆̆ ilinde (Sünnilerde) çok daha belirgin şeklide kendisini hissettirmektedir.

\section{SONUÇ}

İletişim literatüründe farklı kültürlerin karşılaştırılmasında birçok yöntem veya ölçek kullanılmaktadır. Kişilerarası iletişim süreci ise kuşkusuz farklı sosyal parametrelere dayalı olarak ortaya çıkan, değerlerle şekillenen ve çoğu zaman bireyden bağımsız oluşan bir iletişimsel ortam aşamasıdır. İletişim ve etkileşim içerisinde bulunan bireyler, şüphesiz sistem analizinin gereği olarak kesintisiz bir 'dönüt' döngüsü içerisindedirler ve geri bildirim almaktadırlar. Dönüt mekanizmasının pozitif olması, sonuçların değerlendirmeye alınabilmesi ve istenilen yöne evrilebilmesi bireyler arasındaki ilişkinin, iletişimin ve etkileşimin düzeyi ile doğrudan ilintilidir. Ancak burada vurgulanmasi gereken en önemli husus; sosyal ve toplumsal düzeni oluşturan iletişim etkinliklerinin ve eylemlerinin sağlıklı düzleme oturtulması bireylerin niyetlerine ve empatik anlayışa dair olan inançları ile mümkündür.

Alevileri ile Sünniler arasındaki ilişkiye ve iletişime bakıldığında tarihten günümüze değin sağlıklı yürümediği görülmektedir. Zira her iki toplum da oluşturdukları ön yargılar nedeniyle pozitif bir diyaloga geçememişlerdir. Özellikle Osmanlı devleti döneminde Alevi-Sünni mezhep mensupları arasındaki iletişimin (daha ziyade siyasi odaklı gerilimler nedeniyle) pozitif yönde bir seyir izlemediği söylenebilir. Kuşkusuz Osmanl1Safevi devletlerinin Anadolu'daki mücadeleleri de bu iki mezhep mensupları arasındaki iletişimi büyük ölçüde etkilemiştir. Günümüze bakıldığında ise iki mezhep arasındaki önyargıların halen devam ettiğine dair bulgular mevcuttur. Özellikle Alevi toplumuyla ilgili 'mum söndü' ve 'gusülsüz' gibi önyargılar bu olumsuzluklara örnek olarak gösterilebilir. Siyasi anlamda oluşan farklılıkların da sürece önemli oranda etki ettiğini söylemek mümkün görünmektedir. Alevilerin daha çok sol siyasi akımların içinde olması; 'Marksist', 'Ateist', 'Komünist' ve 'Kızıllar' gibi nitelendirilmelerine sebebiyet verirken. Sünnilerin ise daha çok sağ ve muhafazakâr hareketler içinde bulunmaları Aleviler tarafından; 'gerici, 'yobaz', 'milliyetçi' 'ülkücü' şeklinde nitelendirilmelerine dayanak oluşturmuştur. 
İki mezhep arasındaki gerilimlerin daha çok siyasi hareketler nedeniyle şekillendiği pek çok kez vurgulanmıştı. Örneğin bu bağlamda Sivas, Çorum, Maraş ve Gazi mahallesi gibi Alevi toplumuna karşı yapıldığı varsayılan olaylar da iki mezhep arasındaki gerginliğin temel işaretlerini oluşturmaktadır denilebilir. Kültür ve temel ibadet farklılıkları ise kuşkusuz tarafların birbirlerine karşı mesafeli durmalarına yol açabilmektedir. Ayrıca Alevi-Sünni kaynaşmasına aracılık etmesi beklenen evliliklere iki toplumun da karşı duruş sergilediği bilinmektedir. Ancak son dönemlerde bu tabunun özellikle genç kuşaklar tarafından yıkıldığını söylemek mümkün görünmektedir. Alana ilişkin yapılan bazı bilimsel çalışmalar; her iki toplumun birbirlerine karşı hala önyargılar taşıdıklarını, buna karşın aynı ortamlarda bulunmaktan ve aynı okullara gitmekten imtina etmediklerini ve Alevi-Sünni evliliklerine olumlu baktıklarını göstermektedir. Aleviler ile Sünniler arasındaki bu olumsuz iletişimsel ortamların hala devam edip etmediği, şayet olumlu bir seyir gösteriyor ise sürdürülebilir olup olmadığı açık uçlu bir sorudur.

Metodoloji bölümünde de aktarıldığı üzere öngörülen koşullar gereği her ilde en az 192, toplamda ise 384 deneğe ulaşılmış ve katılımcılar araştırmanın nesnelliği açısından rastgele seçilerek istekli olanlara uygulanmıştır. Elazı̆̆ ilinde ankete iştirak eden kadınların oranı $\% 53,6$, erkeklerin oranı ise \% 46,4'tür. Buna karşın Tunceli'de kadınların oranı $\% 52,6$, erkeklerin ise $\% 47,4$ 'tür. Toplamda; $\% 46$ erkek ve $\% 53,1$ kadın denek dağılımının verilerin cinsiyetlere göre değerlendirme yapılabilmesine uygun bir oran teşkil ettiği düşünülmektedir. Ulaşılan deneklerin yaş aralığının özellikle 15-25 yaş arasında $(\% 54,9)$ olması araştırmanın daha ziyade genç kuşağın görüşlerini yansıttı̆̆ına işaret etmektedir. Eğitim düzeyine ilişkin veriler de zaten bunu doğrulamaktadır (araştırmadaki tüm öğrenci kitlesi \% 81,5’tir). Araştırmanın temel nüvesini oluşturan 'mezhep' oranlamasının illere göre dağılımın da ise ciddi farklılıklar mevcuttur. Zira Elazığ ilinin Sünni inanışı temsil edeceği öngörülse de bu ildeki Alevilerin neredeyse Sünni inanışa mensup olanlarla yakın rakamlara ulaştı̆̆ görülmüştür. Bunu durumun nedeni Elazığ iline (Tunceli'den) göç etmiş olan Alevi inanışa mensup vatandaşların yoğunluğuna dayandırılabilir. Buna karşın Tunceli ilindeki Sünni inanışa mensup olanların oranı ise sadece \% 2,0 iken, Alevi oranı \% 84,0'dır. Dolayısıyla Elazı ̆ ilinde ulaşılan deneklerin hem Alevi hem de Sünni görüşü, Tunceli ilindeki deneklerin ise Alevi inanışının düşüncelerini yansıttığı düşünülebilir.

Bu bağlamda araştırmanın başında ortaya konulan hipotezlerin test edilmesine yönelik yürütülen çalışmada şu sonuçlara ulaşılmıştır:

(i) "Denekler kendi inanışlarını bir mezhep olarak tanımlarlar" hipotezi doğrulanmıştır. Her inanış mensubunun kendisini bir dinin parçası olarak değerlendirmesi doğal bir durumdur (toplamdaki oran \% 61,2'dir). Ancak Tunceli ilinde Aleviliği bir din olarak değerlendirenlerin oranının \% 32,3 olması anlamlı bir bulgu olarak dikkat çekmiştir.

(ii) "Denekler kendilerine karşı inanç mensupları tarafından ayrımcılık yapılmasını en itici unsur olarak değerlendirirler" hipotezinin test edilmesinde nesnel değerlendirme yapılabilecek bir sonuç alınamamıştır. Zira 'İslamiyet'i farklı yaşamaları' ve 'mezhepleriyle ilgili yanlış inanışları' seçeneklerinde de yakın sonuçlar alınmıştır. 
(iii) "Denekler karşı inanç mensuplarını Alevi veya Sünni şeklinde tanımlarlar” hipotezi yanlışlanmıştır. Burada ulaşılan genel kanaat her iki inanç mensuplarının bir birlerini "Müslüman” şeklinde tanımlamalarıdır.

(iv) "Deneklerin karşı inanç mensuplarından beklentileri, kedilerine hoşgörülü davranmalarıdır" hipotezinin test edilmesine yönelik yöneltilen soruda 'hoşgörü' seçeneğine ilişkin ciddi bir orana ulaşılsa da (\% 31,8), "Sünnilik/Alevilik ile ilgili yanlış yargıları terk etme" beklentisinin daha baskın olduğu tespit edilmiştir (\% 40,1). Dolayısıyla bu hipotezin yanlışlandığı sonucuna ulaşıldığını söylemek mümkün görünmektedir. Bu bağlamda inanışların birbirlerine karşı hoşgörülü olma beklentisinin yanı sıra özellikle yanlış yargıların terkedilmesi beklentisinin daha elzem bir düşünce olarak ortaya çıktığ 1 söylenebilir.

(v) "Denekler Alevilik ile Sünnilik arasında bir ayrılık görmezler" hipotezi doğrulanmıştır. Oransal olarak bu sonuçlara ulaşılsa da, 'evet', bu inanışlar arasında ayrılık vardır kanaatinin de (\% 47,1 'lik oranla) dikkat çektiği görülmüştür.

(vi) "Denekler, inanışlarının bir mezhebi çağrıştırdığı kanaatini taşırlar" hipotezi yanlışlanmıştır,

(vii) "Denekler karşı inanış mensupları ile daha çok kutsal bayramlarda bir araya gelmeye çalışırlar” hipotezi yanlışlanmıştır. Elde edilen veriler iki inanışın da daha çok ticari alanda ilişki içerisinde olduklarını göstermektedir (\% 55,0).

(viii) "Denekler karşı inanç mensuplarıyla daha çok eğlence ve alış-veriş ortamlarında etkileşim ve iletişim içerisinde olurlar” hipotezi de yanlışlanmıştır. Verilere göre katılımcılar daha çok eğitim alanında etkileşim ve iletişim içerisindedirler $(\% 46,4)$.

(ix) "Denekler karşı inanç mensuplarıyla evliliğe olumlu bakarlar" hipotezi doğrulanmıştır. Bu oran \% 45,1'dir ve 'olumlu' bir sonuç olarak değerlendirilebilir.

(x) "Denekler Alevi-Sünni bütünleşmesinin gerekliliğine inanırlar” hipotezi doğrulanan diğer bir bulgudur. Kısmen seçeneği ile birlikte değerlendirildiğinde oranın \% 67,8 'e ulaştığı görülmektedir ve 'anlamlı' olarak değerlendirilebilecek diğer bulgudur.

(xi) "Denekler karşı inanç mensuplarının baskın olduğu ortamlarda mezhebi aidiyetlerini rahatlıkla söyleyebilirler” hipotezi de doğrulanmıştır. Katılımcılar karşı inanç mensuplarının olduğu ortamlarda kendilerini ifade etmekten imtina etmedikleri (\% 58,8) sonucuna ulaşılması da yine 'anlamlı' bir bulgu olarak değerlendirilmelidir.

\section{KAYNAKÇA}

Adaman, F., \& Keyder, Ç. (2006). Türkiye'de Büyük Kentlerin Gecekondu ve Çöküntü Mahallelerinde Yaşanan Yoksulluk ve Sosyal Dişlanma. (Erişim: 29.01.2015), http://ec. europa. eu/employment_social/social_inclusion/docs/2006/study_turkey_tr. pdf.

Bozkurt, M. (2010). Sünnilik, Şiilik, Alevilik, Vehhabilik Nedir?. Ankara: Özyurt Matbaacılık.

Cırık, İ. (2008). Çok Kültürlü Eğitim ve Yansımaları. Hacettepe Üniversitesi Eğitim Fakültesi Dergisi, (34), 27-40. 
Çarkoğlu, A., \& Toprak, B. (2006). Değişen Türkiye'de Din, Toplum ve Siyaset. İstanbul: TESEV Yayınları.

Dalkıran, S. (2002). Alevî Kimliği ve Anadolu Alevîliği Üzerine Bir Deneme. EKEV Akademi Dergisi, 6(10), 95-118.

Kaptan, S. (1993). Bilimsel Araştırma ve İstatistik Teknikleri. Ankara: Gazi Üniversitesi.

Karasu, M. A. (2008). Türkiye'de Kentleşme Dinamiklerinin Suça Etkisi. Ankara Üniversitesi Hukuk Fakültesi Dergisi, 57(4), 255-281.

Krejcie, R. V., \& Morgan, D. W. (1970). Determining Sample Size for Research Activities. Educational and Psychological Measurement, 30(3), 607-610.

Küpeli, Ö. (2010). Osmanlı-Safevi Münasebetlerine Dair Türkiye'de Yapılan Çalışmalar Hakkında Birkaç Not ve Bir Bibliyografya Denemesi. Tarih Okulu Dergisi, (6), 17 32.

Özmen, A. (2006). Tur Abdin Süryanileri Örneğinde Etno-Kültürel Sinırlar. Yayınlanmamış Doktora Tezi. Ankara: Ankara Üniversitesi.

Üçer, C. (2005). Geleneksel Alevîlikte İbadet Hayatı ve Alevîlerin Temel İslâmî İbadetlere Yaklaşımları. Din Bilimleri Akademik Araştırma Dergisi, 5(2), 161-189.

Ünverdi, M. (2011). Temel İbadetler Konusunda Hanefiler ve Şafiiler Arasındaki Farklar. Yayınlanmamış Yüksek Lisans Tezi. Adana: Çukurova Üniversitesi.

Yapıcı, A. (2009). İçimizdeki Öteki: Kimlik ve Ön Yargı Kıskacında Sünni-Alevi İlişkileri. Dem Dergi, 2(6), 52-59. 
